\title{
Integrated Performance Measurement as a Strategic Management Accounting Approach: A Case of Beverage Businesses in Thailand
}

\author{
Kornchai PHORNLAPHATRACHAKORN ${ }^{1}$, Jindarat PEEMANEE ${ }^{2}$
}

Received: June 05, 2020 Revised: June 28, 2020 Accepted: July 09, 2020

\begin{abstract}
This study aims to examine the effects of integrated performance measurement on firm success of beverage businesses in Thailand. Integrated performance measurement, organizational commitment, organizational citizenship behavior, and firm success are the main variables of the study. In this study, all 653 beverage businesses from Department of Business Development, Ministry of Commerce, Thailand are the samples of the study. The data collection was provided during February - April, 2016. A mail survey procedure via questionnaire was used for data collection. 163 responses were received. Of the surveys completed and returned, 159 were usable. The structural equation model (SEM) is conducted to examine the effects of integrated performance measurement on organizational commitment, organizational citizenship behavior and firm success. The results show that integrated performance measurement positively influences organizational commitment, organizational citizenship behavior and firm success. Organizational commitment positively affects both organizational citizenship behavior and firm success while organizational citizenship behavior positively impacts firm success. In summary, integrated performance measurement as a strategic management accounting approach is a key determinant of firms' business outcome. Firms need to support their resources and capabilities in developing, implementing, utilizing, and maintaining integrated performance measurement. Potential discussion, conclusion, and suggestions and directions for future research are highlighted.
\end{abstract}

Keywords: Integrated Performance Measurement, Organizational Commitment, Organizational Citizenship Behavior, Firm Success

JEL Classification Code: M41

\section{Introduction}

Recently, markets are competitive and environments are highly uncertain. Firms need to create, utilize, and maintain a valuable strategy that can help them deal with and compete against competitors in these markets and environments. They can provide outperforming business operations and activities via implementing these strategies. Strategic management accounting is a source of valuable strategies which enhances firms to achieve success, survival and sustainability in

${ }^{1}$ First Author and Corresponding Author. Associate Professor, Institute for Business and Accounting Innovation, Nakhan Phanom University, Thailand [Postal Address: Nakhon Phanom, 48000, Thailand] Email: kornchai.p@npu.ac.th

${ }^{2}$ AssistantProfessor, Mahasarakham Business School, Mahasarakham University, Thailand. Email: jindarat.p@acc.msu.ac.th

(c) Copyright: The Author(s)

This is an Open Access article distributed under the terms of the Creative Commons Attribution Non-Commercial License (http://Creativecommons.org/licenses/by-nc/4.0/) which permits unrestricted noncommercial use, distribution, and reproduction in any medium, provided the original work is properly cited. the current and future perspectives. In existing literature, strategic management accounting is defined as the provision and analysis of management accounting data and information about a business and its competitors, for use in developing and monitoring business strategies (Simmonds, 1981). It is a key determinant of firms' best business outcome. Better strategic management accounting implementation can promote sustainable competitive advantage and superior performance. In addition, strategic management accounting comprises of five techniques, namely strategic costing, strategic performance measurement, strategic decision making, competitor accounting, and customer accounting (Cadez \& Guilding, 2012).

These techniques are increasingly focused on providing values to customers and firms. They are important drivers of strategic management process under rapidly changing business environments. In this study, strategic performance measurement is considered as a key business strategy that can encourage firms to meet their objectives, goals and purposes in the aforementioned situations and conditions, especially integrated performance measurement. Accordingly, this 
study attempts to investigate the effects of integrated performance measurement on business outcome, including organizational commitment, organizational citizenship behavior and firm success.

Integrated performance measurement is important to support firms to achieve a goal. It is a key business process that critically enables firms to function effectively and efficiently. Here, integrated performance measurement is defined as a comprehensiveness of measures that reflects all relevant features of organizational performance and value and fits with strategic objectives and operations across a value chain (Giovannoni \& Maraghini, 2013). It translates all relevant aspects of organizational performance into financial and non-financial measures and targets, estimates and manages trade-offs to avoid conflicts between different performance dimensions or time periods and manages consensus and ensures an understanding of multiple and diverse measures.

In addition, integrated performance measurement is the most powerful management control mechanism to enhance a probability of successful strategy implementation (Amir, Auzair, \& Ismail, 2014). It significantly affects effectiveness and efficiency of firms' structure, conformity, development, and formalization. To achieve successful integrated performance measurement in an organization, all relevant management accounting data and information in financial and non-financial aspects and other relating issues are fundamental to firms' performance appraisal (Bititci, Carrie, \& McDevitt, 1997). Firms with great integrated performance measurement can result in effective and efficient control and decision making that lead to firms' increased competitiveness, outstanding performance and long-term success in changing competitive markets and environments. Best integrated performance measurement is also likely to promote their operation, practices and activities through providing efforts, behaviors and satisfaction to their employees. Then, firms tend to obtain superior performance and profitability and achieve their success, survival and sustainability. Thus, integrated performance measurement is a main enabler of firms' organizational performance and success.

This study investigates the effects of integrated performance measurement on firm success of beverage businesses in Thailand. Beverage businesses in Thailand are the appropriate samples of the study because these businesses have continuously grown and they have dealt with existing customers and new coming customers. Then, an effective strategic approach and method can encourage firms to achieve success, survival and sustainability in doing business under uncertain competitive markets and environments. The key research question is how integrated performance measurement affects firm success. The specific research questions are: (1) How integrated performance measurement leads to organizational commitment and organizational citizenship behavior, (2) How organizational commitment relates to organizational citizenship and firm success, and (3) How organizational citizenship behavior links to firm success. The remainder of this study is organized as follows. Relevant literature review of integrated performance measurement is addressed and hypotheses development is presented. Next, the research methods are provided and the results and reasonable discussions of the study are shown. Finally, contributions for theory and management, limitations of the study and suggestions and directions for future research are provided.

\section{Literature Review and Hypotheses Development}

According to Barney's study (1991), resource and capability are sources of competitive advantage and performance. In this study, integrated performance measurement is considered as a capability of firms. It explicitly plays a significant role in determining firms' organizational commitment, organizational citizenship behavior and firm success. More integrated performance measurement effectiveness is likely to have a relationship with greater business outcome. Here, integrated performance measurement is the main variable of the study while organizational commitment, organizational citizenship behavior and firm success are the consequent variables of the study. Thus, the hypothesized relationships are shown in Figure 1.

\subsection{Integrated Performance Measurement}

Strategic management accounting is a valuable tool that helps firms effectively perform their operation, practices and activities and outstandingly achieve performance, success, survival, and sustainability in volatile business environments and situations. Great strategic management accounting implementation explicitly determines firms' outcome and consequences. While strategic management accounting includes several techniques, this study emphasizes only on integrated performance measurement as a key accounting approach and method that enables firms to gain success in businesses. In this study, integrated performance measurement refers to a comprehensiveness of measures that reflects all relevant features of organizational performance and value and fits with strategic objectives and operations across a value chain (Giovannoni \& Maraghini, 2013). It is the most appropriate measure that encompasses a comprehensive and consistent manner of organizational performance and ensures a necessary alignment of firms' strategies. It encourages them to increase competitive advantage and performance. Integrated performance measurement is defined as a broader 


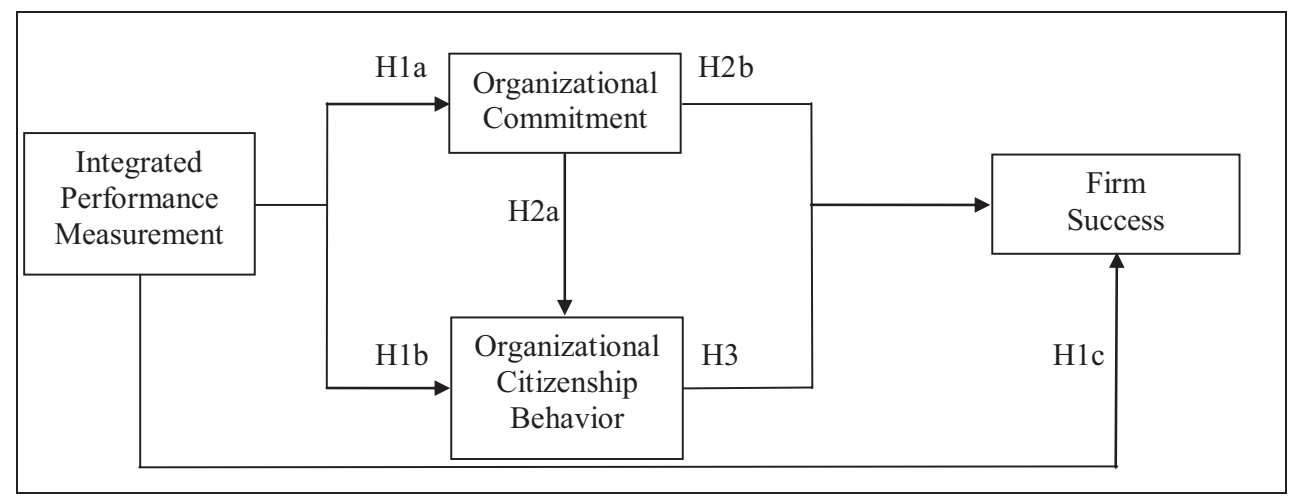

Figure 1: The conceptual model of the relationships between integrated performance measurement and firm success

evaluation process relating to firm's mission and objectives by encompassing a multitude of tools, approaches and methods (Rouse \& Putterill, 2003). It comprises of (a) financial and non-financial measures and targets, (b) different performance dimensions and time periods, (c) multiple and diverse measures, (d) subject and objective frameworks, and (e) short and long-term processes.

In a system of integrated performance measurement, employees work smoothly with comfortable environments and supporting climate. Then, firms can encourage their employees to pay more attention to an organization as committing with their duties and functions, showing good citizenships, and performing faithful behaviors. They also obtain success in their businesses. Accordingly, integrated performance measurement can help firms obtain commitment and citizenship behavior in an organization from their employees and achieve their performance, success, survival and sustainability in the current and future and long terms. Likewise, integrated performance measurement provides a way of translating strategy into a set of performance measures, namely financial and non-financial measures and other tools, approaches, methods, and dimensions (Cadez \& Guilding, 2007). It focuses on overall measurement strategy, alignment between strategy and performance measurement practices, alignment between value drivers and performance measurement practices, and use of measurement alignment techniques (Rompho \& Siengthai, 2012). It influences employee behavior to achieve desired performance, supports continuous improvement and encourages organizational trust in an organization. It enables firms to configure effectiveness and efficiency of firms' operation, practices and activities.

Firms with integrated performance measurement implementation typically emphasize acquiring performance knowledge based on multiple requirements of employees, customers and other stakeholders. They can efficiently meet their objectives, goals and purposes, such as success, survival and sustainability. They tend to gain sustainable competitive advantage and obtain superior performance. Moreover, integrated performance measurement helps firms learn how to be more effective in achieving strategic ends by revealing the relationships between strategies and goals, focusing on a process of supporting a search for strategic advantage, communicating strategy, defining tactics to implement strategy, and monitoring steps toward strategic objectives (Nanni, Dixon, \& Vollmann, 1992). It provides a powerful management control mechanism and framework to enhance successful strategy implementation (Amir, Auzair, \& Ismail, 2014). It positively leads to firms' competitiveness, performance and success in the rapidly changing markets and environments. Thus, integrated performance measurement is likely to have a significant influence on organizational commitment, organizational citizenship behavior and firm success. It is hypothesized to positively relate to the aforementioned outcome. Therefore,

H1: Integrated performance measurement has a positive effect on (a) organizational commitment, (b) organizational citizenship behavior and (c) firm success.

\subsection{Organizational Commitment}

In an implementation of integrated performance measurement, employees are comfortable with environments and climate of fairness, justice and motivation in an organization. They explicitly work in a positive working atmosphere. As a result, they tend to have more commitment with their duties, jobs, functions, and responsibilities. Hence, organizational commitment is a consequence of integrated performance measurement in this study. It refers to a relative strength of an individual's identification with and involvement in a particular organization (Steyrer, Schiffinger, \& Lang, 2008). It is defined as a psychological link between employees and their organization that makes the employees stay in an organization (Wang \& Wong, 
2011). It comprises of affective commitment (an emotional attachment to an organization), continuance commitment (a tendency to maintain a membership of an organization based on recognition of costs associated with departure) and normative commitment (employees' perceived obligation to support an organization and its activities).

Employees with high commitment to the organization are more productive, loyal and responsible and attempt to give firms' superior performance and long-term success in highly competitive markets and environments (Nguyen \& Ngo, 2020). Thus, firms with high organizational commitment can encourage employees to have good citizenship behaviors. They are likely to have more success in business. Additionally, organization commitment involves a strong belief in and acceptance of firms' goals and values, a willingness to exert considerable effort on behalf of firms and a desire to attain membership in the firms (Macedo, Pinho, \& Silva, 2016). It preserves the longevity of firms' businesses and creates positive working environments for their employees. Thus, organizational commitment likely has a positive influence on organizational citizenship behavior and firm success.

In existing literature, organizational commitment is positively related to organizational citizenship behavior (Devece, Palacios-Marques, \& Alguacil, 2016) and firms' success in business (Hitotsuyanagi-Hansel, Froese, \& Pak, 2016). Great organizational commitment enables employees to provide good behaviors in an organization that leads to firms' superior effectiveness, performance and success. Accordingly, organizational commitment positively leads to organizational citizenship behavior and firm success. Interestingly, organization commitment displayed by employees is largely based on their willingness to accept firms' values and strategies and their strong desire to work for a betterment of firms and remain with the firms (Dhar, 2015). It enhances firms to achieve their goals, namely performance, success, survival, and sustainability and provides an opportunity for employees' gains. Therefore, organizational commitment has a significant effect on employee behaviors and firm success.

Furthermore, organizational commitment is an individual's attitude towards an organization and it is reflected in a relative strength of an individual's relationship and identification with the organization (Cichy, Cha, \& Kim, 2009). It is a creativity of positive and fair working conditions and environments that promote employees' good behaviors in an organization. It is a key in guiding and maintaining organizational effectiveness and firm success (Hardiningsih, Udin, Masdjojo, \& Srimindarti, 2020). Hence, organizational commitment explicitly leads to employees' appropriate behaviors relating to firms' objectives, goals and purposes and their resources, assets, capabilities, competencies. Organizational commitment significantly enhances their success in highly rigorous competitive markets and environments. Thus, it is hypothesized to have a positive impact on organizational citizenship behavior and firm success. Therefore,

H2: Organizational commitment has a positive effect on (a) organizational citizenship behavior and (b) firm success.

\subsection{Organizational Citizenship Behavior}

As mentioned earlier, integrated performance measurement is important and it reflects that firms are aware of justice and fairness in their operation, practices and activities that explicitly results in employees' behavioral reactions (Chan \& Lai, 2017). It definitely promotes firms' good employee behaviors in an organization. Also, organizational commitment explicitly relates to organizational citizenship behavior (Devece, Palacios-Marques, \& Alguacil, 2016). Therefore, organizational citizenship behavior is considered as an important outcome of integrated performance measurement and organizational commitment. Here, it is defined as employee behaviors that facilitate organizational effectiveness and promote organizational success (Ozduran $\&$ Tanova, 2017). These behaviors arise from motivations of informal job requirements and informal reward systems. Firms with organizational citizenship behavior can decrease absenteeism and employee turnover rates, increase effective working groups, improve organizational effectiveness, and achieve their success (Dong \& Phuong, 2020).

Likewise, organizational citizenship behavior refers to positive and voluntary employee behaviors that surpass minimum job requirements through helping co-workers, being conscientious toward work environments and communicating new and critical information (Naqshbandi, Singh, \& Ma, 2016). It helps create a positive working atmosphere, protect firms' resources and assets and enhances their success in highly uncertain competitive environments. It comprises of altruism (helping and cooperating behaviors with other colleagues), conscientiousness (behaviors that go beyond minimal requirements and general compliance with rules), sportsmanship (willingness to disregard minor inconveniences that arise in the workplace), courtesy (behaviors aimed at prevention of problems encountered with co-worker), and civic virtue (responsible political involvement) (Lin, Chen, \& Chen, 2016). Hence, organizational citizenship behavior is positively associated with organizational effectiveness, namely productivity and efficiency. It significantly leads to firms' success, survival and sustainability.

Organizational citizenship behavior helps enhance coworkers and managerial productivity, frees up resources to be used by more productive activities, reduces any scarce resources dedicated to purely maintenance functions, coordinates activities with other people, strengthens firms' 
abilities to attract and retain good employees, stabilizes their performance, and adapts effectively to environmental changes (Choi, 2020; Chou, Chou, Jiang, \& Klein, 2013). It explicitly promotes firms' success. In addition, organizational citizenship behavior builds positive working climate and environments, facilitates an accomplishment of organizational goals, enhances customer satisfaction and organizational performance and increases firms' effectiveness, success and survival (Yen \& Teng, 2013). Interestingly, organizational citizenship behavior presents employees' willingness to remain with an organization, actions that surpass their job description and proactive behavior beyond job responsibilities (Chiang \& Hsieh, 2012). It creates proactive cooperation and assistance among co-workers and encourages employees to do good things for their organization. Firms with organizational citizenship behavior can build positive and voluntary working climate and environments that enhance employees to act and practice effectively and efficiently. Firms are likely to achieve their success in businesses. Effective organizational citizenship behavior is importantly related to firms' superior success. Thus, it is hypothesized to have a positive influence on firm success. Therefore,

H3: Organizational citizenship behavior has a positive effect on firm success.

\section{Research Methods}

\subsection{Sample and Data Collection}

In this study, all 653 beverage businesses from Department of Business Development, Ministry of Commerce, Thailand are the samples of the study. The data collection was provided during February 1-April 30, 2016. A mail survey procedure via questionnaire was used for data collection. Accounting executives are key informants of the study. These informants include chief financial officers, accounting directors and accounting managers. They have taken the highest responsibilities of accounting functions and other related activities in an organization. With regard to the questionnaire mailing, 163 responses were received. Of the surveys completed and returned, 159 were usable. The effective response rate was approximately $24.35 \%$. According to Aaker, Kumar, and Day (2001), the response rate for a mail survey, with an appropriate follow-up procedure of greater than $20 \%$ is considered acceptable.

To test potential non-response bias, the assessment and investigation of non-response-bias were centered on a comparison of the first and the second wave data as recommended by Armstrong and Overton (1977). In this regard, neither procedure showed significant differences because there were no statistically significant differences between first and second groups at a 95\% confidence level as firm age $(t=0.10, \mathrm{p}>.05)$, firm size $(\mathrm{t}=0.11, \mathrm{p}>.05)$ and firm capital $(\mathrm{t}=0.09, \mathrm{p}>.05)$.

\subsection{Measures}

All constructs were measured using a 5-point Likert scale $(1=$ strongly disagree to $5=$ strongly agree $)$, except for firm size, firm age, and firm capital. Appendix A presents the measurements of all variables in this study. Integrated performance measurement, organizational commitment, organizational citizenship behavior, and firm success are the main variables of the study. Integrated performance measurement refers to a comprehensiveness of measures that reflects all relevant features of organizational performance and value and fits with strategic objectives and operations across a value chain (Giovannoni \& Maraghini, 2013). Ten-item scale was developed to gauge how firms provide their performance measurements by using financial and non-financial measures and targets, different performance dimensions and time periods, multiple and diverse measures, subject and objective frameworks, and short and long-term processes. Next, organizational commitment is defined as a relative strength of an individual's identification with and involvement in a particular organization (Steyrer, Schiffinger, \& Lang, 2008). Five-item scale was created to assess how employees show emotional attachment to an organization, maintain a membership of an organization based on recognition of costs associated with departure and perceive obligation to support an organization and its activities.

In addition, organizational citizenship behavior refers to positive and voluntary employee behaviors that surpass minimum job requirements through helping co-workers, being conscientious toward work environments and communicating new and critical information (Naqshbandi, Singh, \& Ma, 2016). Six-item scale was initiated to evaluate how employees help and cooperate behaviors with other colleagues, go beyond minimal requirements and general compliance with rules, disregard minor inconveniences that arise in the workplace, aim at prevention of problems encountered with co-worker, and provide responsible political involvement. Lastly, firm success is defined as a goal achievement of businesses through efficient, effective and excellent operation, practices and activities. Five-item scale was introduced to assess how firms obtain market acceptance, customer satisfaction, executive satisfaction, increased profit margin, and market share growth.

\subsection{Instrument Test}

To test the quality of research instrument, both validity and reliability were employed. Firstly, factor analysis was 
conducted separately on each set of the items representing a particular scale due to limited observations. This analysis has a high potential to inflate the component loadings. All factor loadings with values of $0.56-0.91$ are greater than the 0.40 cut-off and are statistically significant (Nunnally \& Bernstein 1994). Secondly, discriminant power was implemented to assess the validity of the measurements by item-total correlation. In the scale validity, item-total correlation with values of 0.48-0.90 is greater than 0.30 (Churchill, 1979). Thirdly, the reliability of the measurements was evaluated by Cronbach alpha coefficients. In the scale reliability, Cronbach alpha coefficients with values of $0.74-0.85$ are greater than 0.70 (Nunnally \& Bernstein, 1994). The scales of all measures appear to produce internally consistent results and they are deemed appropriate for further analysis. Thus, they express an accepted validity and reliability in this study.

Table 1 presents the results for factor loadings, item-total correlation and Cronbach alpha for multiple-item scales used in this study. The structural equation model (SEM) is conducted to examine the effects of integrated performance measurement on organizational commitment, organizational citizenship behavior and firm success. Because all variables in this study were neither nominal data nor categorical data, the structural equation model is an appropriate method for examining the hypothesized relationships.

\section{Results and Discussion}

In Table 2, the descriptive statistics and correlation matrix for all variables are presented. Multicollinearity might occur when inter-correlation in each predict variable is more than 0.80 , which is a high relationship (Hair, Black, Babin, \& Anderson, 2010). The correlations ranging from 0.21 to 0.69 at the $\mathrm{p}<0.01$ level, which means that the possible relationships of the variables in the conceptual model could be tested. Thus, there are no substantial multicollinearity problems encountered in this study.

Table 3 presents the results of path coefficients and hypotheses testing of the research relationships. Figure 2 shows a summary of the integrated performance measurementfirm success relationships. In this study, the goodness of fit of the models is verified, namely the goodness of fit index (GFI) with value of 0.97 , the comparative fit index (CFI) with value of 0.99 , the incremental fit index (IFI) with value of 0.95 , and the root mean square error of approximation (RMSEA) with value of 0.03 are considered (Herda \& Lavelle, 2012). Thus, the initial test of the measurement model results is a good fit to the data. GFI value is an index that ranges from 0 to 1 , with value over 0.90 indicating a relatively good fit (Byrne, 1998) while CFI values always lie between 0 and 1 , with values over 0.90 indicating a relatively good fit (Bentler, 1990). In addition, IFI values exceeding 0.90 indicate a relatively good fit (Kline, 1998) and a RMSEA value of less than 0.05 indicates a close fit and less than 0.08 suggests a marginal fit (Bollen \& Long, 1993).

Interestingly, the effects of integrated performance measurement on organizational commitment, organizational citizenship behavior and firm success are investigated. Firstly, integrated performance measurement definitely has a positive influence on organizational commitment (b

Table 1: Results of measure validation

\begin{tabular}{|l|c|c|c|}
\hline Items & Factor Loadings & Item-total Correlation & Cronbach alpha \\
\hline Integrated performance measurement (IP) & $0.74-0.88$ & $0.48-0.75$ & 0.85 \\
\hline Organizational commitment (OC) & $0.76-0.87$ & $0.58-0.81$ & 0.74 \\
\hline Organizational citizenship behavior (OB) & $0.56-0.86$ & $0.59-0.88$ & 0.80 \\
\hline Firm success (FS) & $0.76-0.91$ & $0.78-0.90$ & 0.81 \\
\hline
\end{tabular}

Table 2: Descriptive statistics and correlation matrix

\begin{tabular}{|l|c|c|c|c|}
\hline \multicolumn{1}{|c|}{ Variables } & IP & OC & OB & FS \\
\hline Mean & 4.12 & 3.80 & 4.00 & 3.73 \\
\hline s.d. & 0.41 & 0.54 & 0.54 & 0.65 \\
\hline IP & & & & \\
\hline OC & $0.44^{* * *}$ & & & \\
\hline OB & $0.46^{* * *}$ & $0.55^{* * *}$ & & \\
\hline FS & $0.48^{* * *}$ & $0.58^{* * *}$ & $0.31^{* *}$ & \\
\hline
\end{tabular}

${ }^{* *} p<.05,{ }^{* * *} p<.01$ 
Table 3: Results of path coefficients and hypotheses testing

\begin{tabular}{|l|c|c|c|c|}
\hline \multicolumn{1}{|c|}{ Hypotheses } & Relationships & Coefficients & t-value & Results \\
\hline $\mathrm{H} 1 \mathrm{a}$ & $\mathrm{IP} \rightarrow \mathrm{OC}$ & $0.32^{*}$ & 1.90 & Supported \\
\hline $\mathrm{H} 1 \mathrm{~b}$ & $\mathrm{IP} \rightarrow \mathrm{OB}$ & $0.46^{* * *}$ & 3.31 & Supported \\
\hline $\mathrm{H} 1 \mathrm{c}$ & $\mathrm{IP} \rightarrow \mathrm{FS}$ & $0.39^{* *}$ & 2.34 & Supported \\
\hline $\mathrm{H} 2 \mathrm{a}$ & $\mathrm{OC} \rightarrow \mathrm{OB}$ & $0.47^{* * *}$ & 4.49 & Supported \\
\hline $\mathrm{H} 2 \mathrm{~b}$ & $\mathrm{OC} \rightarrow \mathrm{FS}$ & $0.81^{* * *}$ & 5.32 & Supported \\
\hline $\mathrm{H} 3$ & $\mathrm{OB} \rightarrow \mathrm{FS}$ & $0.29^{*}$ & 1.83 & Supported \\
\hline
\end{tabular}

${ }^{*} p<.10,{ }^{* *} p<.05,{ }^{* * *} p<.01$

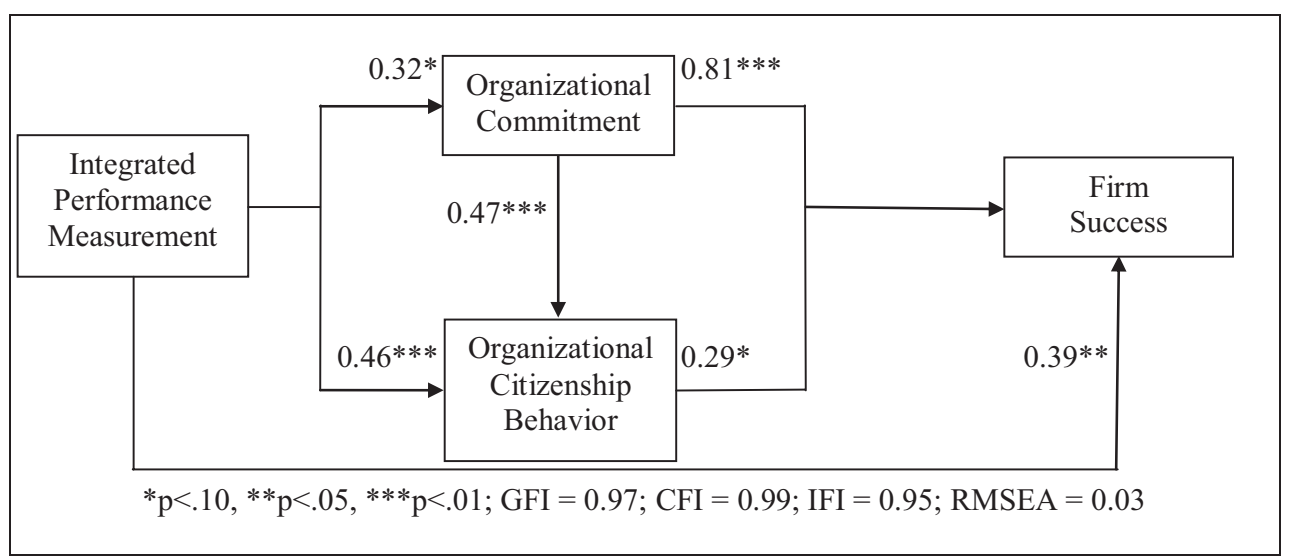

Figure 2: A summary of the relationships between integrated performance measurement and firm success

$=0.32, p<0.06)$, organizational citizenship behavior $(\mathrm{b}=$ $0.46, p<0.01)$ and firm success $(b=0.39, p<0.05)$. In existing literature, integrated performance measurement is a comprehensiveness of measures that reflects all relevant features of organizational performance and value and fits with strategic objectives and operations across a value chain (Giovannoni \& Maraghini, 2013). It encompasses a multitude of tools, approaches and methods, namely financial and non-financial measures and targets, different performance dimensions and time periods, multiple and diverse measures, subject and objective frameworks, and short and long-term processes (Rouse \& Putterill, 2003). Firms with successful integrated performance measurement implementation can encourage their employees to pay more attention to an organization by committing to their duties and functions, being good citizenships, and acting faithful behaviors. They tend to increase commitment and citizenship behavior in an organization from their employees and achieve their outstanding success in the competitive markets and environments. Thus, integrated performance measurement positively leads to organizational commitment, organizational citizenship behavior and firm success. Therefore, Hypotheses 1a-1c are supported.
Secondly, organizational commitment is also important to determine firms' citizenship behavior and success. In this study, organizational commitment explicitly has a positive effect on organizational citizenship behavior ( $\mathrm{b}=$ $0.47, p<0.01)$ and firm success $(b=0.81, p<0.01)$. Here, organizational commitment is a relative strength of an individual's identification with and involvement in a particular organization (Steyrer, Schiffinger, \& Lang, 2008). It is a psychological link between employees and their organization that makes the employees stay in an organization (Wang \& Wong, 2011). It preserves the longevity of firms' businesses and creates positive working environments for their employees. Firms with high commitment of employees are more productive, loyal and responsible and attempt to affect firms' superior performance and long-term success in highly competitive markets and environments. Accordingly, firms can encourage employees to have good citizenship behaviors and they also achieve superior success. Thus, organizational commitment plays a significant role in determining, driving and explaining organizational citizenship behavior and firm success. It is positively related to organizational citizenship behavior and firm success. Therefore, Hypotheses $2 \mathrm{a}-2 \mathrm{~b}$ are supported. 
Thirdly, organizational citizenship behavior is a main determinant of firm success. It critically has a positive impact on firm success $(b=0.29, p<0.08)$. It reflects positive and voluntary employee behaviors that surpass minimum job requirements through helping co-workers, being conscientious toward work environments and communicating new and critical information (Naqshbandi, Singh, \& Ma, 2016). It helps and cooperates behaviors with other colleagues, employees go beyond minimal requirements and general compliance with rules, disregard minor inconveniences that arise in the workplace, aim at prevention of problems encountered with co-workers, and be responsible political involvement (Lin, Chen, \& Chen, 2016). Organizational citizenship behavior significantly leads to firms' success, survival and sustainability. Firms with citizenship behavior of employees can build positive and voluntary working climate and environments that enhance employees to act and perform effectively and efficiently and can achieve their success in business operation, practices and activities. Effective citizenship behavior is importantly related to their outstanding success. Thus, organizational citizenship behavior positively leads to firm success. It enhances firms to obtain more success in highly rigorous competitive situations and conditions. Therefore, Hypotheses 3 is supported.

In summary, integrated performance measurement is a strategic business tool that helps employees provide great commitment in an organization and provide good actions, responsibilities and practices. It also encourages firms to achieve increased success in the current and future and long terms. Hence, integrated performance measurement positively relates to organizational commitment, organizational citizenship behavior and firm success while organizational commitment positively enhances organizational citizenship behavior and firm success. Likewise, organizational citizenship behavior positively affects firm success.

\section{Contributions and Directions for Future Research}

\subsection{Theoretical Contribution}

This study attempts to verify and prove the effects of integrated performance measurement on organizational commitment, organizational citizenship behavior and firm success. Here, the relationships among integrated performance measurement organizational commitment, organizational citizenship behavior, and firm success are empirically confirmed. These results are congruent with the theory of the resource-based views of the firms. To expand and increase the contributions of the current study, future research needs to search for antecedents of integrated performance measurement and moderators of the research relationships in order to create more benefits and values of the study. Also, future research needs to collect data from different populations or larger populations in order to test the generalizability of the study through using a comparative study or a cross-cultural study. In addition, future research may need to apply, implement and employ other valuable statistical techniques, such as regression analysis, path analysis and partial least squared (PLS) in order to verify the results of the study and prove the generalizability of the study.

\subsection{Managerial Contribution}

Integrated performance measurement is important to create employees' commitment and citizenship behavior in an organization and encourage firms to achieve success in highly uncertain competitive markets and environments. It definitely plays a significant role in determining, driving and explaining firms' organizational commitment, organizational citizenship behavior and organizational success. Accordingly, firms can implement and utilize integrated performance measurement as a strategic valuable tool to help gain competitive advantage, profitability, success, survival, and sustainability. To effectively provide integrated performance measurement, executives of firms need to support an implementation of integrated performance measurement via allocating and investing their resources, assets, capabilities, competencies, and potentialities to the implementation. Likewise, these executives also need to provide valuable factors and antecedents in order to promote the success of integrated performance measurement.

\section{Conclusion}

Integrated performance measurement is a valuable strategic business approach and method that helps firms gain competitive advantage and achieve success, survival and sustainability in competitive markets and environments. Thus, it is important to determine firms' success. This study attempts to investigate the relationships among integrated performance measurement, organizational commitment, organizational citizenship behavior, and firm success. The objective of this study is to examine the effects of integrated performance measurement on firm success of beverage businesses in Thailand. In this study, 159 beverage businesses in Thailand are the samples of the study. This study employs structural equation model (SEM) to test the research relationships. The results indicate that integrated performance measurement has a positive effect on organizational commitment, organizational citizenship behavior, and firm success. Next, organizational commitment has a positive impact on both organizational citizenship behavior and firm success. In addition, organizational 
citizenship behavior has a positive influence on firm success. To achieve more benefits and contributions of integrated performance measurement implementation, firms need to allocate and invest their resources, assets, competencies, capabilities, and potentialities to the implementation and provide valuable factors and antecedents that affect the implementation. To verify and expand the current study, future research needs to search for the antecedents and factors of the study, collect data from different populations or larger populations and employ other statistical techniques to test the generalizability of the study.

\section{References}

Aaker, D. A., Kumar, V., \& Day, G. S. (2001). Marketing research. New York, NY: John Wiley and Sons.

Amir, A. M., Auzair, S. M., \& Ismail, Z. (2014). Integrated performance measurement system in small and medium enterprises: the role of leadership and decision-making style. Asian Journal of Accounting and Governance, 5, 47-56.

Armstrong, J. S., \& Overton, T. S. (1977). Estimating non-response bias in mail surveys. Journal of Marketing Research, 14(3), 396-402.

Barney, J. (1991). Firm resources and sustained competitive advantage. Journal of Management, 17(1), 99-120.

Bentler, P. M. (1990). Comparative fit indices in structural models. Psychological Bulletin, 107, 238-246.

Bititci, U. S., Carrie, A. S., \& McDevitt, L. (1997). Integrated performance measurement systems: a development guide. International Journal of Operations and Production Management, 17(5), 522-534.

Bollen, K. A., \& Long, J. S. (1993). Testing structural equation models. Thousand Oaks, CA: Sage Publications.

Byrne, B. M. (1998). Structural equation modeling with LISREL, Prelis and Simplis: basic concepts, applications and programming. Mahwah, NJ: Lawrence Erlbaum Associates.

Cadez, S., \& Guilding, C. (2007). Benchmarking the incidence of strategic management accounting in Slovenia. Journal of Accounting and Organizational Change, 3(2), 126-146.

Cadez, S., \& Guilding, C. (2012). Strategy, strategic management accounting, and performance: a configurational analysis. Industrial Management and Data, 112(3), 484-501.

Chan, S. H. J., \& Lai, H. Y. I. (2017). Understanding the link between communication satisfaction, perceived justice, and organizational citizenship behavior. Journal of Business Research, 70, 214-223.

Chiang, C., \& Hsieh, T. (2012). The impacts of perceived organizational support and psychological empowerment on job performance: the mediating effects of organizational citizenship behavior. International Journal of Hospitality Management, 31, 180-190.
Choi, Y. (2020). A study of role of perceived organizational support among sexual harassment and employees' attitudes. Journal of Asian Finance, Economics, and Business, 7(2), 229-236. https://doi.org/10.13106/jafeb.2020.vol7.no2.229

Chou, T., Chou, S. T., Jiang, J. J., \& Klein, G. (2013). The organizational citizenship behavior of IS personnel: does organizational justice matter?. Information and Management, 50, 105-111.

Churchill, G. A., Jr. (1979). A paradigm for developing better measures of marketing constructs. Journal of Marketing Research, 16(February), 64-73.

Cichy, R. F., Cha, J., \& Kim, S. (2009). The relationship between organizational commitment and contextual performance among private club leaders. International Journal of Hospitality Management, 28, 53-62.

Devece, C., Palacios-Marques, D., \& Alguacil, M. P. (2016). Organizational commitment and its effects on organizational citizenship behavior in a high-unemployment environments. Journal of Business Research, 69(5), 1857-1861.

Dhar, R. L. (2015). Service quality and the training of employees: the mediating role of organizational commitment. Tourism Management, 46, 419-430.

Dong, L. N. T., \& Phuong, N. N. D. (2018). Organizational justice, job satisfaction and organizational citizenship in higher education institutions: a research proposition in Vietnam. Journal of Asian Finance, Economics, and Business, 5(3), 113-119. http://doi.org/10.13106/jafeb.2018.vol5.no3.113

Giovannoni, E., \& Maraghini, M. P. (2013). The challenges of integrated performance measurement systems: integrating mechanisms for integrated measures. Accounting, Auditing, and Accountability Journal, 26(6), 978-1008.

Hair, J. F., Black, W. C., Babin, B. J., \& Anderson, R. E. (2010). Multivariate data analysis: a global perspective $\left(7^{\text {th }}\right.$ ed.). Upper Saddle River, NJ: Person Prentice Hall.

Hardiningsih, P., Udin, U., Masdjojo, G. N., \& Srimindarti, C. (2020). Does competency, commitment, and internal control influence accountability?. Journal of Asian Finance, Economics, and Business, 7(4), 223-233. https://doi.org/10.13106/jafeb.2020. vol7.no4.223

Herda, D. N., \& Lavelle, J. J. (2012). The auditor-audit firm relationship and its effect on burnout and turnover intention. Accounting Horizons, 26(4), 707-723.

Hitotsuyanagi-Hansel, A., Froese, F. J., \& Pak, Y. S. (2016). Lessening the divide in foreign subsidiaries: the influence of localization on the organizational commitment and turnover intention of host country nationals. International Business Review, 25, 569-578.

Kline, R. B. (1998). Principles and practices of structural equation modeling. New York, NY: The Guilford Press.

Lin, S., Chen, H., \& Chen, I. (2016). When perceived welfare practices lead to organizational citizenship behavior. Asia Pacific Management Review, 21, 204-212. 
Macedo, I. M., Pinto, J. C., \& Silva, A. M. (2016). Revisiting the link between mission statements and organizational performance in the non-profit sector: the mediating effect of organizational commitment. European Management Journal, 34, 36-46.

Nguyen, H. M., \& Ngo, T. T. (2020). Psychological capital, organizational commitment and job performance: a case in Vietnam. Journal of Asian Finance, Economics, and Business, 7(5), 269-278. https://doi.org/10.13106/jafeb.2020.vol7. no5.269

Nanni, A. J., Jr., Dixon, J. R., \& Vollmann, T. E. (1992). Integrated performance measurement: management accounting to support the new manufacturing realities. Journal of Management Accounting Research, 4, 1-19.

Naqshbandi, M. M., Singh, S. K. G., \& Ma, P. (2016). The link between organizational citizenship behaviors and open innovation: a case of Malyasian high-tech sector. IIMB Management Review, 28, 200-211.

Nunnally, J. C., \& Bernstein, I. H. (1994). Psychometric theory. New York, NY: McGraw-Hill.

Ozduran, A., \& Tanova, C. (2017). Coaching and employee organizational citizenship behaviors: the role of procedural justice climate. International Journal of Hospitality Management, 60, 58-66.

Rompho, B., \& Siengthai, S. (2012). Integrated performance measurement system for firm's human capital building. Journal of Intellectual Capital, 13(4), 482-514.

Rouse, P., \& Putterill, M. (2003). An integral framework for performance measurement. Management Decision, 41(8), 791-805.

Simmonds, K. (1981). Strategic management accounting. Management Accounting, 59(4), 26-30.

Steyrer, J., Schiffinger, M., \& Lang, R. (2008). Organizational commitment-A missing link between leadership behavior and organizational performance?. Scandinavian Journal of Management, 24, 364-374.

Wang, J., \& Wong, C. (2011). Understanding organizational citizenship behavior from a cultural perspective: an empirical study within the context of hotels in Mainland China. International Journal of Hospitality Management, 30, 845-854.

Yen, C., \& Teng, H. (2013). The effect of centralization on organizational citizenship behavior and deviant workplace behavior in the hospitality industry. Tourism Management, 36, 401-410. 
Appendix A: Measurement of all variables

\begin{tabular}{|c|}
\hline Items \\
\hline Integrated Performance Measurement (IP) \\
\hline $\begin{array}{l}\text { 1. We believe that integrated performance measurement can help firms increase competitive advantage and obtain their } \\
\text { success, survival and sustainability in the competitive markets and environments. }\end{array}$ \\
\hline $\begin{array}{l}\text { 2. We pay attention in integrating performance measurements systematically and objectively that help achieve } \\
\text { operational goals better. }\end{array}$ \\
\hline $\begin{array}{l}\text { 3. We emphasize an implementation of performance measurement by using all types of measurement tools in order to } \\
\text { effectively respond to the competitive environments. }\end{array}$ \\
\hline $\begin{array}{l}\text { 4. We focus on developing and improving performance measurement tools by using modern and advanced technology } \\
\text { that promote firms' creativity and innovation continuously. }\end{array}$ \\
\hline $\begin{array}{l}\text { 5. We employ both financial and non-financial measures in evaluating firms' performance that helps achieve operational } \\
\text { goals under the competitive situations efficiently. }\end{array}$ \\
\hline $\begin{array}{l}\text { 6. We implement short and long-term indicators in assessing firms' outcomes that can encourage firms to provide } \\
\text { development and improvement of their operations in the current and future aspects. }\end{array}$ \\
\hline $\begin{array}{l}\text { 7. We have a confidence that both subjective and objective measurements can enhance firms to gain their success, } \\
\text { survival and sustainability continuously. }\end{array}$ \\
\hline $\begin{array}{l}\text { 8. We believe that past performance can affect firms' current performance while the current performance can predict their } \\
\text { future performance. }\end{array}$ \\
\hline $\begin{array}{l}\text { 9. We apply multiple and diverse measures of performance in an organization that can encourage firms to operate their } \\
\text { businesses successfully. }\end{array}$ \\
\hline $\begin{array}{l}\text { 10. We utilize different dimensions of performance measurements, such as customer satisfaction, market acceptance, } \\
\text { corporate reputation, and profitability that help firms achieve efficiency, effectiveness and success. }\end{array}$ \\
\hline Organizational Commitment (OC) \\
\hline $\begin{array}{l}\text { 1. We believe that employees' commitment in an organization can enhance to gain sustainable competitive advantage } \\
\text { and achieve superior performance. }\end{array}$ \\
\hline 2. Our employees have always acted an emotional attachment to an organization. \\
\hline $\begin{array}{l}\text { 3. Our employees have continuously maintained a membership of an organization based on recognition of costs } \\
\text { associated with departure. }\end{array}$ \\
\hline 4. Our employees have explicitly perceived obligations to support an organization and its activities. \\
\hline $\begin{array}{l}\text { 5. Our employees have identified with and involved in an organization through enthusiasm, working hard, creativity, and } \\
\text { job improvement. }\end{array}$ \\
\hline Organizational Citizenship Behavior (OB) \\
\hline $\begin{array}{l}\text { 1. We believe that employees' good behaviors can build a positive working atmosp } \\
\text { competitiveness, success, survival and sustainability in the highly rigorous com }\end{array}$ \\
\hline 2. Our employees always help and cooperate behaviors with other colleagues. \\
\hline 3. Our employees go beyond minimal requirements and general compliance with rules. \\
\hline 4. Our employees disregard minor inconveniences that arise in the workplace. \\
\hline 5. Our employees aim at prevention of problems encountered with co-worker. \\
\hline 6. Our employees provide responsible political involvement. \\
\hline Firm Success (FS) \\
\hline 1. We have obtained growth of profit margin continuously from past to now. \\
\hline 2. We have gained more increased market share than competitors under the rigorous competitive environments. \\
\hline 3. We have achieved market acceptance through efficient, effective and excellent businesses. \\
\hline 4. Our executives have satisfied our previous business outcomes continuously. \\
\hline 5. Our customers have satisfied our business operations, practices and activities. \\
\hline
\end{tabular}

